University of Nebraska - Lincoln

DigitalCommons@University of Nebraska - Lincoln

2005

\title{
Inter-species variation in yolk steroid levels and a cowbird-host comparison
}

D. Caldwell Hahn

Patuxent Wildlife Research Center, chahn@usgs.gov

Jeff S. Hatfield

Patuxent Wildlife Research Center, jhatfield@usgs.gov

Mahmoud A. Abdelnabi

University of Maryland

Julie M. Wu

University of Maryland

Lawrence D. Igl

USGS Northern Prairie Research Center, ligl@usgs.gov

See next page for additional authors

Follow this and additional works at: https://digitalcommons.unl.edu/usgsnpwrc

Part of the Other International and Area Studies Commons

Hahn, D. Caldwell; Hatfield, Jeff S.; Abdelnabi, Mahmoud A.; Wu, Julie M.; Igl, Lawrence D.; and Ottinger, Mary A., "Inter-species variation in yolk steroid levels and a cowbird-host comparison" (2005). USGS Northern Prairie Wildlife Research Center. 186.

https://digitalcommons.unl.edu/usgsnpwrc/186

This Article is brought to you for free and open access by the US Geological Survey at DigitalCommons@University of Nebraska - Lincoln. It has been accepted for inclusion in USGS Northern Prairie Wildlife Research Center by an authorized administrator of DigitalCommons@University of Nebraska - Lincoln. 
Authors

D. Caldwell Hahn, Jeff S. Hatfield, Mahmoud A. Abdelnabi, Julie M. Wu, Lawrence D. Igl, and Mary A. Ottinger

This article is available at DigitalCommons@University of Nebraska - Lincoln: https://digitalcommons.unl.edu/ 


\title{
Inter-species variation in yolk steroid levels and a cowbird-host comparison
}

\author{
D. Caldwell Hahn, Jeff S. Hatfield, Mahmoud A. Abdelnabi, Julie M. Wu, Lawrence D. Igl and \\ Mary A Ottinger
}

Hahn, D. C., Hatfield, J. S., Abdelnabi, M. A., Wu J. M., Igl, L. D. and Ottinger, M. A. 2005. Inter-species variation in yolk steroid levels and a cowbird-host comparison. - J. Avian Biol. 36: 40-46.

\begin{abstract}
We examined variability in yolk hormone levels among songbird species and the role of yolk steroids as a mechanism for enhanced exploitation of hosts by the parasitic brownheaded cowbird Molothrus ater. Within-clutch variation in yolk steroids has been found in several avian species in single species studies, but few comparisons have been made among species. We found a large range of differences in yolk testosterone among the seven passerine species examined, with significant differences between those at the high end (song sparrow Melospiza melodia, red-winged blackbird Agelaius phoeniceus, and house sparrow, Passer domesticus) and those at the low end (eastern phoebe Sayornis phoebe, and house finch Carpodacus mexicanus). We also found that the testosterone level in cowbird eggs was intermediate in relation to host species levels and was significantly lower than that in three common cowbird hosts (song sparrow, redwinged blackbird, and house sparrow), but not significantly different from three others. Geographical comparisons of yolk testosterone levels in all cowbird subspecies and populations from several regions showed no significant differences, though a trend that deserves further exploration was the pattern of lowest level in the ancestral population of cowbirds in the central prairies and of highest level in the northwestern population where range invasion occurred approximately 40 years ago. The levels of 17 betaestradiol were similar in the seven songbird species examined, which is consistent with current hypotheses that this hormone plays a role in embryonic sexual differentiation. Further investigation is needed to determine whether the large differences observed among species in absolute level of yolk testosterone are the relevant focal point or whether target tissue sensitivity differences mediate the effects of this yolk steroid, particularly between parasitic and non-parasitic species.
\end{abstract}

D. C. Hahn (correspondence) and J. S. Hatfield, USGS, Patuxent Wildlife Research Center, 12100 Beech Forest Road, Laurel, MD 20708-4034, USA. E-mail: Caldwell_Hahn@usgs.gov.M. Abdelnabi,J.Wu and M.A. Ottinger, Department of Animal and Avian Sciences, University of Maryland, College Park, MD 20742. L. D. Igl, USGS, Northern Prairie Research Center, 8711 37th St. SE, Jamestown, ND 58401-7317.

We investigated the variability of yolk steroid hormones among songbird species with particular attention to differences between the brown-headed cowbird Molothrus ater, and some of its host species. Recent studies of hormonal content in avian eggs have shown significant within-clutch variation in many species (e.g. canary Serinus canaria, Schwabl 1993, cattle egret Bubulcus ibis, Schwabl et al. 1997, red-winged blackbird Agelaius phoeniceus, Lipar et al. 1999, gulls Larus marinus, Royle et al. 1999, common tern Sterna hirundo, French et al. 2001, American coot Fulica amerficana, Reed and Vleck 2001, European starling Sturnus vulgaris, Lipar 2001). Schwabl $(1993,1996)$ found that higher yolk testosterone levels effect higher nestling growth rates and greater begging vigor in canaries. Several authors have suggested that female birds may manipulate the level of testosterone in eggs they lay in order to increase or decrease the relative behavioral dominance and feeding success 
among their nestling offspring (Schwabl 1993, Schwabl et al. 1997, Lipar et al. 1999, Lipar and Ketterson 2000), although there is not yet evidence whether the variance in yolk steroid levels reflects actively stored steroids in eggs that benefit some young at the expense of others or whether the variance in yolk steroids is merely a passive reflection of female physiology during laying.

We hypothesized that there is significant inter-species variability in yolk steroid levels and that the parasitic brown-headed cowbird might deposit elevated testosterone levels in its eggs as a mechanism to exploit host species. Ornithologists have long been aware that cowbird nestlings are particularly aggressive and competitive at feeding time (Payne 1977, Lowther 1993) and Lichtenstein and Sealy (1998) used video cameras to document quantitatively that cowbird nestlings were fed more often than yellow warbler chicks due to greater begging vigor and more frequent begging calls. Independently Ortega and Cruz (1991) showed that cowbird nestlings have a significantly higher growth rate than that of a close relative and common host, the yellowheaded blackbird Xanthocephalus xanthocephalus. However, no information exists on the mechanism(s) underlying these traits.

To carry out this study of inter-species variation, we collected eggs from both cowbirds and six songbirds parasitized by cowbirds. We collected in four areas across North America representing geographic areas where cowbirds and hosts have co-existed for different periods of time, due to the dramatic increase in the cowbird's range since European colonization of North America (Rothstein 1994, Hahn and O'Connor 2001). Differences in duration of sympatry could result in differences in relative levels of yolk testosterone, since current arms-race evolutionary theory predicts that host defenses and parasite strategies co-evolve (Rothstein 1975, Dawkins and Krebs 1979, Davies and Brooke 1988, Lotem and Nakamura 1998).

We also investigated the pattern of yolk estradiol differences among species, because little is known about inter-species patterns in this yolk steroid in songbirds, and the possibility of differences between species of different taxonomic origin or of contrasting parasitic and host life history made an exploratory investigation useful. We hypothesized that the inter-species variation in levels of yolk estradiol would be significantly less than that of yolk testosterone levels, because estradiol appears to play a conservative role in avian sexual differentiation (Adkins-Regan et al. 1991, 1995).

\section{Methods}

\section{Study species}

The brown-headed cowbird is the principal North American brood parasite (Lowther 1993). It is now abundant across the continent, having expanded its original range in the central prairies in association with human colonization and invaded many new habitats (Rothstein 1994, Hahn and O'Connor 2001, Morrison and Hahn 2002). Cowbirds are extreme host generalists that parasitize over 200 songbird species from several families, although a smaller number constitute the most frequently parasitized host species and cowbirds display some regional differences in parasitism patterns (Payne 1977, Lowther 1993). Song sparrow Melospiza melodia, and eastern phoebe Sayornis phoebe, are major hosts in the cowbird's ancestral range in the central prairies as well as in the cowbird's invaded eastern and western ranges. Red-winged blackbird is a major host in both the ancestral central range and in the more recently invaded western range. House sparrow Passer domesticus, eastern bluebird Sialia sialis, and house finch Carpodacus mexicanus, are less frequent hosts that are parasitized primarily in the cowbird's invaded eastern range.

\section{Egg collection}

We collected cowbird eggs from four geographical areas of the United States where the cowbird has been present for contrasting periods of time: (1) north central United States (Jamestown, North Dakota), (2) south-central U.S. (Fort Hood, Texas and Carlsbad National Park, New Mexico), (3) northwestern U.S. (Seattle, Washington), (4) eastern mid-Atlantic U.S. (Millbrook, New York, Laurel, Maryland, Prince George's County; and Leesburg, Virginia, Table 1).

We also collected eggs from six species that serve as cowbird hosts: song sparrow, eastern phoebe, red-winged blackbird, house sparrow, eastern bluebird, and house finch. These species represent a range of taxonomic families, hosts parasitized nationally or regionally, and hosts parasitized frequently or occasionally.

\section{Radio immunoassay}

Eggs were collected prior to incubation. Once collected, eggs were frozen at $-20^{\circ} \mathrm{C}$ for the duration of the breeding season. Eggs were then thawed at room temperature, yolks were separated from albumen, and $50 \mathrm{mg}$ of homogenized yolk were weighed and refrozen at $-80^{\circ} \mathrm{C}$ until extraction could be completed. Subsequently, yolk estradiol and testosterone were extracted in an excess of ethyl acetate and hexane, and the extract was layered on a celite column according to previously validated specifications (Moore 1986, Schwabl 1993).

Tritiated steroid hormones (estradiol and testosterone) were added to the homogenate for calculation of extraction and purification recoveries. Estradiol and testosterone were measured by single antibody (Esoterix) 
Table 1. Comparison of yolk steroid levels among four subspecies and populations of brown-headed cowbirds. No significant differences were found, although there is a suggestive trend in yolk testosterone from the lowest level in the ancestral population to the highest level in the northwestern population occupying the most recently invaded range ${ }^{1}$.

\begin{tabular}{|c|c|c|c|c|c|c|}
\hline $\begin{array}{l}\text { Brown-headed cowbird } \\
\text { Molothrus ater } \\
\text { Subspecies/Population }\end{array}$ & $\begin{array}{l}\text { Sample size } \\
(\mathrm{N})\end{array}$ & State & Range & $\begin{array}{l}\text { Duration of } \\
\text { range }^{2}\end{array}$ & $\begin{array}{l}\text { Yolk testosterone } \\
\text { Mean } \pm \text { SE } \\
(\mathrm{pg} / \mathrm{mg})\end{array}$ & $\begin{array}{l}\text { Yolk estradiol } \\
\text { Mean } \pm \text { SE } \\
\quad(\mathrm{pg} / \mathrm{mg})\end{array}$ \\
\hline $\begin{array}{l}\text { Molothrus ater } \\
\text { (grand mean) }\end{array}$ & 48 & & & & $1.519 \pm 1.222$ & $0.654 \pm 1.181$ \\
\hline $\begin{array}{l}\text { Subspecies or population: } \\
\text { (a) Molothrus ater ater }\end{array}$ & 5 & ND & $\begin{array}{l}\text { Central } \\
\text { prairies }\end{array}$ & Ancestral & $0.546 \pm 1.669$ & $1.021 \pm 1.530$ \\
\hline (b) M.a. obscurus & 27 & TX, NM & Southwestern & $\begin{array}{l}\text { Invaded } \\
\text { (hundreds }\end{array}$ & $1.575 \pm 1.247$ & $0.437 \pm 1.201$ \\
\hline (c) M.a. ater & 9 & $\mathrm{MD}, \mathrm{VA}, \mathrm{NY}$ & Eastern & $\begin{array}{l}\text { Invaded } \\
\text { (hundreds }\end{array}$ & $2.085 \pm 1.465$ & $0.593 \pm 1.373$ \\
\hline (d) M.a. extimus & 7 & WA & Pacific & $\begin{array}{l}\text { Invaded } \\
\text { (40 years) }\end{array}$ & $2.973 \pm 1.542$ & $0.691 \pm 1.433$ \\
\hline
\end{tabular}

${ }^{1}$ A repeated measures analysis of variance was used, along with a $\log 10$ transformation, to calculate these summary statistics (back-transformed least square means and standard errors) for testosterone and estradiol of brown-headed cowbird and to perform pairwise comparisons among populations and subspecies.

${ }^{2}$ Rothstein 1994.

radio immunoassay (RIA) using methods similar to previous assays in our laboratory (Ottinger and Mahlke 1984, Adkins-Regan et al. 1995). Validation of these assays was conducted for all species in the study. Validation included measurements of serial dilutions of yolk samples, determination of accuracy of known concentrations added to the extract, as well as calculation of inter- and intra-assay $\% \mathrm{CV}$, which was below $10 \%$. The sensitivity of the RIAs was $10-15$ picogram/ $\mathrm{mg}$. The assay sensitivity is generally $2-5 \mathrm{pg} /$ tube, and the amount measured in a tube is then corrected to the amount extracted originally (mg).

\section{Statistics}

We used SAS (SAS 1996) to perform a repeated measures analysis of variance (ANOVA) on the variables of both testosterone and estradiol, assuming a compound symmetry variance-covariance structure. Since the detection limit was $0.10 \mathrm{pg} / \mathrm{mg}$, this value was substituted for any zero values before analysis, and the data were then transformed using the $\log 10$ transformation in order to stabilize variances and help achieve normality of the residuals. Each ANOVA assumed that eggs of a given host species collected from the same nest were correlated, but that all cowbirds and individuals of host species from different nests were independent of each other. We generated least square means and t-test contrasts to test for differences (i) among cowbirds from the four populations and subspecies, (ii) between the grand mean for cowbirds vs. each of the six host species and (iii) among the six host species. Sequential Bonferroni adjustments (Rice 1989) were used to maintain the overall $\alpha$-level of each set of contrasts at $\alpha<0.05$. Least square means and standard errors were back-transformed before presentation.

\section{Results}

\section{Geographical comparisons among cowbird populations}

Table 1 shows the relative levels of yolk steroids in eggs of four different cowbird populations. There were no significant differences among cowbird populations in androgen or estradiol concentrations in the yolk. Sequential Bonferroni adjustments imply that statistical significance of differences in pairwise comparisons should be inferred only if $\mathrm{P} \leq 0.0029$ for testosterone and $\mathrm{P} \leq 0.0019$ for estradiol to maintain an overall $\alpha$-level of $\alpha \leq 0.05$ for each set of contrasts. Since none of the cowbird-cowbird pairs were significantly different, all cowbird samples were placed in one group in subsequent statistical analyses and comparisons among species.

\section{Yolk androgen concentrations}

Table 2 compares the levels of yolk steroids of seven songbird species. The six non-parasitic species showed a large variation in levels of yolk testosterone, from the highest level (house sparrow, $21.351 \mathrm{pg} / \mathrm{mg}$ ), which was more than 60 times greater than the lowest level (house finch, $0.286 \mathrm{pg} / \mathrm{mg}$ ). Differences among non-parasitic species clustered at three levels: high (yolk testosterone levels greater than $16 \mathrm{pg} / \mathrm{mg}$ ), 
Table 2. Comparison of yolk steroid levels in cowbirds and six host species. A repeated measures analysis of variance (ANOVA) was used, along with a $\log 10$ transformation, to control for the lack of independence of eggs collected from the same nest. Subsequent t-test contrasts were generated from the ANOVA to compare each pair of means between species for each variable ${ }^{1}$. Note: For cowbird-host comparisons, significant differences are indicated in bold. For host-host comparisons, significant differences are indicated by superscripts $\left({ }^{\mathrm{a}} \mathrm{vs}^{\mathrm{b}}\right)$.

\begin{tabular}{|c|c|c|c|c|c|c|}
\hline Species & $\begin{array}{l}\text { Number } \\
\text { of nests }\end{array}$ & $\begin{array}{l}\text { Number } \\
\text { of eggs }\end{array}$ & $\begin{array}{l}\text { Yolk testosterone } \\
\text { Mean } \pm \text { SE } \\
(\mathrm{pg} / \mathrm{mg})\end{array}$ & $\begin{array}{l}\text { Cowbird - Host } \\
\text { comparisons } \mathrm{P}^{2}\end{array}$ & $\begin{array}{l}\text { Yolk estradiol } \\
\text { Mean } \pm \text { SE } \\
(\mathrm{pg} / \mathrm{mg})\end{array}$ & $\begin{array}{l}\text { Cowbird - Host } \\
\text { comparisons } \mathrm{P}^{2}\end{array}$ \\
\hline $\begin{array}{l}\text { Brown-headed cowbird } \\
\text { (grand mean from Table 1) }\end{array}$ & 46 & 48 & $1.519 \pm 1.222$ & - & $0.654 \pm 1.181$ & - \\
\hline \multicolumn{7}{|l|}{ Cowbird hosts ${ }^{3}$ : } \\
\hline House sparrow & 4 & 15 & $21.351^{\mathrm{a}}+1.434$ & $<0.0001$ & $1.841^{\mathrm{a}}+1.410$ & 0.0088 \\
\hline Song sparrow & 5 & 9 & $16.991^{\mathrm{a}} \pm 1.526$ & $<\mathbf{0 . 0 0 0 1}$ & $2.062^{\mathrm{a}} \pm 1.454$ & 0.0068 \\
\hline Red-winged blackbird & 7 & 11 & $10.262^{\mathrm{ab} \pm 1.446}$ & $<0.0001$ & $0.578^{\mathrm{a}} \pm 1.379$ & 0.7347 \\
\hline Eastern bluebird & 4 & 14 & $2.362^{\mathrm{bc}} \pm 1.449$ & 0.2995 & $2.420^{\mathrm{a}} \pm 1.420$ & 0.0013 \\
\hline Eastern phoebe & 1 & 4 & $0.342^{c}+2.023$ & 0.0462 & $0.445^{\mathrm{a}}+1.968$ & 0.5823 \\
\hline House finch & 1 & 4 & $0.286^{\mathrm{c}} \pm 2.023$ & 0.0261 & $0.589^{\mathrm{a}} \pm 1.968$ & 0.8820 \\
\hline
\end{tabular}

${ }^{1}$ Each t-test contrast had 60 degrees of freedom. Sequential Bonferroni adjustments imply that statistical significance should be inferred only if $\mathrm{P} \leq 0.0019$ for estradiol and $\mathrm{P} \leq 0.0029$ for testosterone, to maintain an overall $\alpha$-level of $\mathrm{P} \leq 0.05$ for the 27 pairwise comparisons performed in Table 1 and 2 between 4 cowbird populations (6 comparisons), the grand mean of the cowbird populations vs host species (6 comparisons), and the comparisons between host species (15 comparisons).

${ }^{2}$ This $\mathrm{p}$-value compares the grand mean of the cowbird populations to the mean of each of the host species in the preceding column (testosterone or estradiol).

${ }^{3}$ Host species means are not significantly different from each other at an overall $\alpha$-level of $\mathrm{P} \leq 0.05$ if they are annotated with a common superscript. The P-values for these between-host comparisons are not shown, but those identified in the text as significantly different had $\mathrm{P} \leq 0.0019$ for estradiol or $\mathrm{P} \leq 0.0029$ for testosterone, as required by the sequential Bonferroni adjustments.

${ }^{\mathrm{a}, \mathrm{b}, \mathrm{c}} \mathrm{A}$ host group's mean is not significantly from other host group means if they share a common superscript.

intermediate, and low (less than $0.3 \mathrm{pg} / \mathrm{mg}$ ), and significant differences among the non-parasitic species are indicated by different superscripts following the means in Table 2. Specifically, song sparrow and house sparrow (group "a") showed significantly higher levels of yolk testosterone than eastern phoebe and house finch (group "c"). Red-winged blackbird and eastern bluebird showed an intermediate level of yolk testosterone that differed significantly from only some of the species higher and lower. Although only 1 nest (4 eggs each) was sampled for eastern phoebe and house finch, the estimates of the mean and standard error are valid assuming that the assumptions of the ANOVAs are valid. The small sample size is reflected in the large standard error of this mean, which lowered the statistical power of the comparison between the mean of this species and the others. Despite the small sample size for these two species, we included these data to establish a preliminary baseline since these are the first published measurements on yolk estradiol for either species and the first yolk testosterone measurements for house finch.

Cowbirds had an intermediate level of yolk testosterone $(1.519 \mathrm{pg} / \mathrm{mg})$ compared to the six host species examined. The cowbird level was significantly lower than that of the three host species with levels greater than $10 \mathrm{pg} / \mathrm{mg}$ (house sparrow, song sparrow, and red-winged blackbird), and cowbirds did not differ significantly from the three host species that had lower yolk testosterone levels, all less than $2.5 \mathrm{pg} / \mathrm{mg}$ (eastern bluebird, eastern phoebe and house finch).

\section{Yolk estradiol levels}

The range of differences in yolk estradiol levels among all seven songbird species $(2.420-0.445 \mathrm{pg} / \mathrm{mg})$ was much smaller than that observed for yolk testosterone levels. No significant differences in estradiol levels were found among the six non-parasitic species examined (all in group "a"). The only significant difference observed between the cowbird and a host species was with eastern bluebird.

\section{Discussion}

\section{Large inter-species differences in yolk testosterone, but target tissue sensitivity unknown}

The large range of differences reported here in yolk testosterone levels among songbird species is consistent with mounting evidence of both intra- and inter-species variation in this steroid hormone and with increasing curiosity about whether inter-species differences in target tissue sensitivity mediate the effects of these differences in hormone level (Dufty et al. 2002, Schwabl and Lipar 2002, Hauber and Pilz 2003). Since it is appears that yolk testosterone differences correspond reliably to egg laying order in some species (Schwabl 1993, Schwabl et al. 1997, Lipar et al. 1999), the study of within-clutch differences in yolk testosterone has been established as a substantive area of research. However, the interpretation of inter-species differences, especially those 
between parasite and host, is slowed by the potentially confounding factor of species' differences in target tissue sensitivity.

\section{Intermediate levels of yolk testosterone in cowbird eggs compared to six host species}

Our finding that cowbirds have an intermediate yolk testosterone level relative to six host species is based on samples from all cowbird subspecies and from geographically separate populations of cowbirds, including some from both ancestral and invaded ranges. A similar cowbird-host pattern was reported by Hauber and Pilz (2003) for cowbirds and two host species in New York. The results in both studies appear to suggest that cowbirds do not depend on elevated yolk testosterone for the behavioral aggressiveness and elevated growth rates observed in cowbird nestlings vis a vis some host nestlings. However, final conclusions about the significance of parasite-host differences in yolk testosterone levels cannot be reached until investigators conduct inter-species studies of target tissue sensitivity, so that we understand what are the effective species-specific levels of yolk testosterone.

Hahn et al. (2003) reported that small host species most vulnerable to the detrimental effects of cowbird parasitism showed elevated levels of yolk testosterone in response to parasitism. This suggests that the proper focus for studies of the role of yolk testosterone in host defenses against cowbirds, rather than a role in exploitation of hosts by cowbirds. Since the significant difference they reported between parasitized and non-parasitized nests is a within-species difference, it is not subject to the caution necessary in interpreting between-species differences related to possible differences in target tissue receptivity.

Hahn et al. (2003) also reported significantly lower levels of yolk testosterone in cowbird eggs laid in singly parasitized nests than those laid in multiply parasitized nests, this suggests that in cowbirds the focus of selection for yolk testosterone level may be competition among cowbird females rather than competition between cowbird and host females. This finding is consistent with earlier work on non-parasitic species that has similarly shown that differences in yolk steroids occur among individual females in response to population density and female-female competition (Schwabl 1996, Reed and Vleck 2001, Mazuc et al. 2003). Again, this within-species difference between cowbird females is not affected by the issue of possible differences in target tissue sensitivity between cowbird and host species.

\section{Geographical and subspecies comparisons among cowbird eggs}

Our finding reported here that yolk testosterone levels in cowbird eggs from widely separated populations were not significantly different appears to suggest that this yolk steroid did not change in relation to cowbirds' invasion of new geographic ranges and exploitation of new hosts. However, it is worth noting the apparent trend from lowest yolk testosterone level in the North Dakota cowbird population, which occupies the species' ancestral range, to the highest yolk testosterone level in the Washington state cowbird population, which occupies the most recently invaded range (Rothstein 1994; Table 1). Larger differences among cowbird populations may be found if larger sample sizes are collected from both ancestral and invaded populations, particularly if these collections distinguish between singly vs multiply parasitized nests as well as between early vs late nests season.

\section{Yolk estradiol levels similar across species}

Our finding of similar levels of yolk estradiol in these songbird species is consistent with the findings of French et al. (2001) and with the interpretation by many investigators that estradiol has a critical role in sex differentiation in vertebrates (Adkins-Regan et al. 1991, 1995, Conley et al. 1997, Janzen et al. 1998, Williams 1999, Petrie et al. 2001). Further exploration of other hormones such as prolactin, for which investigators have recently found significant variation (Reed and Vleck 2001, Petrie et al. 2001), may also yield interesting cowbird-host differences.

Our data are consistent with recent research (Birkhead et al. 2000, Sockman and Schwabl 2000) indicating that patterns of yolk testosterone are more complex and less consistent among birds than was initially hypothesized (Schwabl 1993). Strategic within-clutch deposition of yolk testosterone has not been found in every species examined (e.g. house wrens, Ellis et al. 2001; zebra finches Taeniopygia guttata, Ward et al. 2001, tree swallows Tachycineta bicolor, Whittingham and Schwabl 2002; or American kestrels, Falco sparverius, Sockman and Schwabl 2001). In some cases yolk androgens may have negative effects on development (Hillgarth et al. 1997, Ros et al. 1997, Hasselquist et al. 1999, Sockman and Schwabl 2000), and Royle et al. (2001) speculated that the presence of higher levels of antioxidants in gull eggs was an adaptation to oppose the effect of elevated testosterone. Elevated yolk androgens may also have limited effectiveness in overcoming the disadvantages associated with hatching asynchrony (Schwabl 1996, Royle and Hamer 1998). Given the widespread developmental effects of androgens (Staub and DeBeer 1997) 
and the fact that hormones typically act on several target tissues with both adaptive effects and non-selected effects (Ketterson and Nolan 1999), investigators must systematically explore the significance when they find consistent patterns of yolk testosterone differences. Given the incomplete state of our understanding of yolk testosterone effects, it is also important to keep an open mind in deciphering the patterns of differences, especially in host-parasite studies.

Acknowledgements - This work was supported by the National Geographic Society, Grant No. 6664-99 to DCH. We thank A. Loughlin, J. Koloszar, R. Clapp, S. Bard, D. Roemer, and T. Haramis for assistance with collection of eggs. Assistance with radioimmunoassays was provided by Erin Quigley. We appreciate helpful discussion with J. Lipar, J. T. Richie, K. Sockman, S. Schoech, and comments that improved the ms from the editor and two anonymous reviewers.

\section{References}

Adkins-Regan, E., Abdelnabi, M., Mobarak, M. and Ottinger, M. A. 1991. Sex steroid levels in developing and adult male and female zebra finches (Poephila guttata). - General Comp. Endocrinol 78: 93-109.

Adkins-Regan, E., Ottinger, M. A. and Park, J. 1995. Maternal transfer of estradiol to egg-yolks alters sexual differentiation of avian offspring. - J. Exp. Zool. 271: 466-470.

Birkhead, T., Schwabl, H. and Burke, T. 2000. Testosterone and maternal effects-integrating mechanisms and function. - Trends Ecol. Evol. 15: 86-87.

Conley, A. J., Elf, P., Corbin, C. J., Dubowsky, S., Fivizzani, A. and Lang, J. W. 1997. Yolk steroids decline during sexual differentiation in the alligator. - General Comp. Endocrinol 107: 191-200.

Davies, N. B. and Brooke, M. de L. 1988. Cuckoos versus reed warblers: adaptations and counter-adaptations. - Anim. Behav. 36: 262-284.

Dawkins, R. and Krebs, J. R. 1979. Arms races between and within species. - Proc. R. Soc. Lond. B 265: 673-678.

Dufty, A. M., Clobert, J. and Møller, A. P. 2002. Hormones, developmental plasticity, and adaptation. - Trends Ecol. Evol. 17: 190-196.

Ellis, L. A., Borst, D. W. and Thompson, C. F. 2001. Hatching asynchrony and maternal androgens in egg yolks of house wrens. - J. Avian Biol. 32: 26-30.

French, J. C. B., Nisbet, I. C. T. and Schwabl, H. 2001. Maternal steroids and contaminants in common tern eggs: a mechanism of endocrine disruption? - Comp. Biochem. Physiol. C 128: 91-98.

Hahn, D. C. and O'Connor, R. J. C. 2001. Contrasting determinants of abundance in the ancestral and colonized ranges of an invasive species. - In: Scott, J. M., Heglund, P. J. and Morrison, M. L. (eds). Predicting species occurrences: issues of scale and accuracy. Island Press, Covello, CA, p. 867 .

Hahn, D. C., Wingfield, J. C., Fox, D. M., Walker, B. G. and Richie, J. T. 2003. Environmental endocrinology and invasive cowbird species.. - In: Abstracts of the Ecological Society of America 88th Annual Meeting, Savannah, GA. - Ecological Society of America, Washington, D.C.

Hasselquist, D., Marsh, J. A., Sherman, P. W. and Wingfield, J. C. 1999. Is avian humoral immunocompetence suppressed by testosterone. - Behav. Ecol. Sociobiol. 45: 167-175.

Hauber, M. E. and Pilz, K. M. 2003. Yolk testosterone levels are not consistently higher in the eggs of obligate brood parasites than their hosts. - Am. Midland Nat. 149: 354362.
Hillgarth, N., Ramonofsky, M. and Wingfield, J. C. 1997. Testosterone and sexual selection. - Behav. Ecol. 8: 108109.

Janzen, F. J., Wilson, M. E., Tucker, J. F. and Ford, S. P. 1998. Endogenous yolk steroid hormones in turtles with different sex-determining mechanisms. - General Comp. Endocrinol. 111: 306-317.

Ketterson, E. D. and Nolan, V. 1999. Adaptation, exaptation, and constraint: a hormonal perspective. - Am. Nat. 154: S4-25.

Lichtenstein, G. and Sealy, S. G. 1998. Nestling competition, rather than supernormal stimulus, explains the success of parasitic brown-headed cowbird chicks in yellow warbler nests. - Proc. R. Soc. Lond. B 265: 249-254.

Lipar, J. L. 2001. Yolk steroids and the development of the hatching muscle in nestling European starlings. - J. Avian Biol. 32: 231-238.

Lipar, J. L., Ketterson, E. D. and Nolan, V. 1999. Intraclutch variation in testosterone content of red-winged blackbird eggs. - Auk 116: 231-235.

Lotem, A. and Nakamura, H. 1998. Evolutionary equilibria in avian brood parasitism. - In: Rothstein, S. I. and Robinson, S. K. (eds). Parasitic birds and their hosts: studies in coevolution. Oxford University Press, NY.

Lowther, P. E. 1993. Brown-headed cowbird. - In: Poole, A. and Gill, F. (eds). The birds of North America. No. 47. Academy of Natural Sciences, Philadelphia, and American Ornithologists Union, Washington, D.C, pp. 1-24.

Mazuc, J., Bonneaud, C., Chastel, O. and Sorci, G. 2003. Social environment affects female and egg testosterone levels in the house sparrow (Passer domesticus). - Ecol. Lett. 6: 10841090.

Moore, M. C. 1986. Elevated testosterone levels during nonbreeding season territoriality in a fall-breeding lizard Sceloporus jarrovi. - J. Comp. Physiol. A. 158: 159-163.

Morrison, M. L. and Hahn, D. C. 2002. Geographical variation in cowbird parasitism: the myth of east-west differences. - In: Dobkin, D. S. and George, L. (eds). Effects of habitat fragmentation on western bird populations. - Stud. Avian Biol. 25: 65-72.

Ortega, C. P. and Cruz, A. 1991. A comparative study of cowbird parasitism in yellow-headed blackbirds. - Auk 108: $16-24$.

Ottinger, M. A. and Mahlke, K. 1984. Androgen concentrations in testicular and peripheral blood in the male Japanese quail. - Poultry Sci. 63: 1851-1854.

Payne, R. B. 1977. The ecology of brood parasitism in birds. - Ann. Rev. Ecol. Syst. 8: 1-28.

Petrie, M., Schwabl, H., Brande-Lavridsen, N. and Burke, T. 2001. Maternal investment-sex differences in avian yolk hormone levels. - Nature 412: 498.

Reed, W. L. and Vleck, C. M. 2001. Functional significance of variation in egg-yolk androgens in the American coot. - Oecologia 128: 164-171.

Rice, W. R. 1989. Analyzing tables of statistical tests. - Evolution 43: 223-225.

Ros, A. F. H., Groothuis, T. G. G. and Apanius, V. 1997. The relation among gonadal steroids, immunocompetence, body mass, and behavior in young black-headed gulls (Larus ridibundus ). - Am. Nat. 150: 201-219.

Rothstein, S. I. 1975. Evolutionary rates and host defenses against avian brood parasitism. - Am. Nat. 109: 161-176.

Rothstein, S. I. 1994. Cowbird invasion of the far west: history, causes, and consequences experienced by hosts. - In: Jehl, J. R. and Johnson, N. K. (eds). A Century of avifaunal change in western North America. - Stud. Avian Biol. 15: 301-315.

Royle, N. J. and Hamer, K. C. 1998. Hatching asynchrony and sibling size hierarchies in gulls: effects on parental investment decisions, brood reduction and reproductive success. - J. Avian Biol. 29: 266-272.

Royle, N. J., Surai, P. F., McCartney, R. J. and Speake, B. K. 1999. Parental investment and egg yolk lipid composition in gulls. - Funct. Ecol. 13: 298-306. 
Royle, N. J., Surai, P. F. and Hartley, I. R. 2001. Maternally derived androgens and antioxidants in bird eggs: complementary but opposing effects? - Behav. Ecol. 12: 381-385.

SAS. 1996. Statistical Analysis System (Version 6.12). - SAS Institute, Inc., Cary, NC.

Schwabl, H. 1993. Yolk is a source of maternal testosterone for developing birds. - Proc. Natl. Acad. Sci. USA 90 (24): $11446-11450$.

Schwabl, H. 1996. Maternal testosterone in the avian egg enhances postnatal growth. - Comp. Biochem. Physiol. 114: $271-276$.

Schwabl, H. and Lipar, J. 2002. Hormonal regulation of begging behavior in begging behavior. - In: Wright, J. and Leonard, M. L. (eds). The evolution of begging: competition, cooperation, and communication. Kluwer Academic Publishers, The Netherlands, pp. 221-244.

Schwabl, H, Mock, D. W. and Gieg, J. A. 1997. A hormonal mechanism for parental favouritism. - Nature 386: 231.

Sockman, K. W. and Schwabl, H. 2000. Yolk androgens reduce offspring survival. - Proc. R. Soc. Lond. B 267: 1451-1456.
Sockman, K. W. and Schwabl, H. 2001. Plasma corticosterone in nestling American kestrels: effects of age, handling stress, yolk androgens, and body condition. - General Comp. Endocrinol 122: 205-212.

Staub, N. L. and de Beer, M. 1997. The role of androgens in female vertebrates. - General Comp. Endocrinol 108: 1-24.

Ward, B. C., Nordeen, E. J. and Nordeen, K. W. 2001. Anatomical and ontogenetic factors producing variation in HVc neuron number in zebra fouches. - Brain Res. 904: $318-326$

Williams, T. D. 1999. Parental and first generation effects of exogenous 17 beta-estradiol on reproductive performance of female zebra finches (Taeniopygia guttata). - Horm. Behav. 35: $135-143$.

(Received 8 April 2002, revised 6 April 2004, accepted 6 April 2004.) 